\title{
Erratum to: Social Determinants of Physical Activity Among Adult Asian-Americans: Results from a Population-Based Survey in California
}

\author{
Monideepa B. Becerra $\cdot$ Patti Herring • \\ Helen Hopp Marshak · Jim E. Banta
}

Published online: 2 October 2014

(c) Springer Science+Business Media New York 2014

Erratum to: J Immigrant Minority Health

DOI 10.1007/s10903-014-0074-z

The corresponding author's surname was accepted and published erroneously. It should be Becerra not Bhattacharya Becerra.

The online version of the original article can be found under doi:10.1007/s10903-014-0074-z.

M. B. Becerra $(\bowtie)$ P. Herring · H. H. Marshak Department of Health Promotion and Education, School of Public Health, Loma Linda University, 24951 North Circle Drive, Loma Linda, CA 92350, USA

e-mail: mbecerra@1lu.edu

\section{J. E. Banta}

Department of Health Policy and Management, School of Public Health, Loma Linda University, 24951 North Circle Drive,

Loma Linda, CA, USA 